\title{
Analisis Implementasi Manajemen Berbasis Sekolah di Kecamatan Pantai Labu
}

\author{
Zon Saroha Ritonga \\ Program Studi Pendidikan Guru Sekolah Dasar, Universitas Nahdlatul Ulama Sumatera Utara \\ e-mail: zon.saroha@yahoo.com
}

\begin{abstract}
Abstrak
Salah satu indikator kesuksesan penerapan MBS di sekolah dilihat dari aspek peran serta masyarakat. Peran serta masyarakat khususnya orang tua siswa dalam penyelenggaraan pendidikan selama ini masih minim. Partisipasi masyarakat selama ini pada umumnya sebatas pada dukungan dana, sementara dukungan lain seperti pemikiran, moral, dan bidang barang atau jasa kurang diperhatikan. Penelitian ini bertujuan untuk mengidentifikasi dan mendeskripsikan implementasi manajemen berbasis sekolah, factor yang mendukung serta penghambat dalam implementasi manajemen berbasis sekolah di Kecamatan Pantai Labu. Metode yang digunakan dalam penelitian ini yaitu dengan pendekatan penelitian kualitatif. Pengumpulan data penelitian diperoleh dengan teknik triangulasi melalui observasi, wawancara dan dokumen. Hasil penelitian ini mengungkapkan temuan bahwa peran serta masyarakat dalam implementasi manajemen berbasis sekolah masih minim, kurangnya pemahaman kepala sekolah tentang batasan keterlibatan masyarakat dalam pengelolaan sekolah merupakan paktor dominan. Keterlibatan masyarakat sebagai bagian dari komite sekolah masih sebatas formalitas untuk melengkapi struktur sekolah.
\end{abstract}

Kata Kunci: Peran Serta Masyarakat, Manajemen Berbasis Sekolah, Pendidikan

\section{Analysis of The Implementation School-Based Management in Pantai Labu Sub-District}

\author{
Zon Saroha Ritonga \\ Program Studi Pendidikan Guru Sekolah Dasar, Universitas Nahdlatul Ulama Sumatera Utara \\ e-mail:zon.saroha@yahoo.com
}

\begin{abstract}
One indicator of the successful implementation of School Based Management at the school level is seen from the aspect of community participation. The role of the community, especially parents of students in the administration of education so far is still minimal. Public participation so far has generally been limited to financial support, while other supports such as thought, morals, and the field of goods or services have been overlooked. This study aims to identify and describe the the implementation of schoolbased management, factors that support and inhibit the implementation of school-based management in Pantai Labu Sub-district. The method used in this study is a qualitative research approach. Research data collection was obtained by triangulation techniques through observation, interviews and documents. The results of this study reveal findings that community participation in the implementation of school-based management is still minimal, the lack of understanding of principals about the limitations of community involvement in school management is the dominant factor. Community involvement as part of the school committee is still limited to formalities to complete the school structure.
\end{abstract}

Keywords: Community Participation, School Based Management, Education 


\section{PENDAHULUAN}

Ada beberapa alasan diterapkannya Manajemen Berbasis Sekolah di Indonesia, yaitu sistem pemerintah Indonesia yang baru mengalami perubahan besar dan masih terus berkembang. Ssistem pendidikan, kebijakan yang mendukung dan pengalaman Indoensia dimasa lalu dianggap sebagai guru terbaik bagi perbaikan pendidikan Indonesia (Wicaksono, 2018). Sistem pemerintahan Indonesia cenderung berubah sejalan dengan suasana masyarakat yang menghendaki desentralisasi, transparansi, demokratisasi, akuntabilitas serta dorongan peningkatan peran masyarakat dalam hampir semua kebijakan dan layanan publik termasuk sistem pendidikan (Prayudi, 2014). Landasan hukum atau kebijakan disebarluaskannya MBS adalah UU No. 22/1999 tentang Pemerintah Daerah (Aziz, 2015), PP No. 25/2000 tentang Kewenangan Pemerintah dan Kewenangan Provinsi sebagai Daerah Otonom, UU No. 25/2000 tentang Propenas, UU No. 122/2003 tentang Sistem Pendidikan Nasional, dan Kepmendiknas No. 122/U/2001 tentang Rencana Strategis Pembangunan Pendidikan, Pemuda dan Olahraga tahun 2000-2004.UU No. 20/2003 dengan tegas menyatakan bahwa MBS merupakan prinsip pengelolaan pendidikan.

Sebagai kebijakan baru, MBS tidak berdiri sendiri, tetapi merupakan rangkaian dari seperangkat kebijakan yang saling terkait dan berhubungan dengan standar nasional, kurikulum berbasis kompetensi, evaluasi yang independen, akreditasi, sertifikasi, profesionalisme ketenagaan, pengalokasian dana dan sumber daya pendidikan lainnya, serta partisipasi masyarakat melalui Dewan Pendidikan dan Komite Sekolah/Madrasah, yang semuanya bertujuan untuk meningkatkan pemerataan dan mutu pendidikan, relevansi dan efisiensi serta akuntabilitas penyelenggaraan dan pengelolaan pendidikan (Umaedi, Hadiyanto, \& Siswantari, 2015).

Salah satu indikator kesuksesan penerapan MBS di sekolah dilihat dari aspek peran serta masyarakat (Risno, 2015). Peran serta masyarakat khususnya orang tua siswa dalam penyelenggaraan pendidikan selama ini masih minim. Partisipasi masyarakat selama ini pada umumnya sebatas pada dukungandana, sementara dukungan lain seperti pemikiran, moral, dan bidang barang atau jasa kurang diperhatikan. Akuntabilitas sekolah terhadap masyarakat juga lemah, sekolah tidak merasa berkeharusan untuk mempertanggung jawabkan hasil pelaksanan pendidikan kepada masyarakat, khususnya orang tua siswa, sebagai salah satu unsur utama yang berkepentingan dengan pendidikan (stakeholder).

Berkaitan dengan peran serta masyarakat dalam Implementasi Manajemen Berbasis Sekolah pada pendidikan dasar maka dapat dilihat beberapa masalah dalam observasi awal peneliti yang dapat diidentifikasi. Seperti yang terjadi di SDN 
106448 Bagan Serdang peran serta masyarakat belum berjalan baik. Masyarakat yang terlibat dalam komite sekolah hanya orang tua siswa saja, belum terlihat adanya peran tokoh agama, budaya serta dunia usaha dan industry dalam komite sekolah. Peran komite sekolah juga belum maksimal, hal tersebut dapat dilihat dari minimnya keterlibatan komite sekolah dalam pengambilan keputusan di sekolah tersebut.

Berdasarkan kenyataan tersebut tentu saja dilakukan upaya-upaya perbaikan, salah satunya adalah melakukan reorientasi penyelenggaraan pendidikan dengan melibatkan peran serta masyarakat melalui manajemen berbasis sekolah.Peran serta masyarakat menjadi penting karena pendidikan merupan kegiatan yang berlangsung di tengah masyarakat itu sendiri, bahkan dilakukan oleh masyarakat dan dimanfaatkan pula oleh masyarakat.Dapat pula dikatakan bahwa berhasil atau tidaknya pendidikan dapat dipengaruhi oleh masyarakat dan hasil pendidikan akan mempengaruhi masyarakat.

Berdasarkan fenomena di atas, maka penelitian ini mengarah kepada pendeskripsian kondisi objektif Peran Serta Masyarakat dalam Implementasi Manajemen Berbasis Sekolah pada Pendidikan Dasar Kecamatan Pantai Labu Kabupaten Deli Serdang Provinsi Sumatera Utara. Hal ini penting dilaksanakan mengingat masih kurangnya peran serta masyarakat di tingkat sekolah yang dapat meningkatkan mutu pendidikan.

\section{METODE}

Metode penelitian yang digunakan adalah metode penelitian kualitatif. Hal tersebut didasarkan pada pertimbangan tujuan penelitian yaitu untuk menggambarkan suatu fenomena, mengenai peran serta masyarakat dalam implementasi Manajemen Berbasis Sekolah pada Pendidikan Dasar di Kecamatan Pantai Labu, maka pengambilan data dilakukan peneliti dengan cara berbaur dengan sekolah dan masyarakat kecamatan Pantai Labu.

Penelitian ini dilakukan di kecamatan Pantai Labu Kabupaten Deli Serdang Provinsi Sumatera Utara. Adapun alasan pemilihan lokasi penelitian ini adalah karena berdasarkan prapenelitian bahwa peran serta masyarakat dalam implementasi Manajemen Berbasis Sekolah di kecamatan Pantai Labu masih lemah hal tersebut dibuktikan masih terbatasnya pemahaman sekolah dan masyarakat tentang pentingnya peran aktif masyarakat disekolah.

Penentuan sampel menggunakan teknik purposive sampling, yaitu teknik penentuan sampel dengan pertimbangan tertentu. Pemilihan teknik purposive sampling dalam penelitian ini dianggap relevan oleh peneliti. Adapun subjek dalam penelitian ini adalah sekolah SD dan Masyarakat di kecamatan Pantai Labu. 
Teknik pengumpulan data merupakan langkah yang paling utama dalam penelitian, karena tujuan utama dari penelitian karena tujuan utama dari penelitian adalah mendapatkan data. Untuk mendapatkan kelengkapan informasi atau data yang sesuai dengan fokus penelitian maka teknik pengumpulan data yang digunakan sebagai berikut.

Observasi. Observasi dapat diklasifikasikan menjadi observasi berpartisipasi, observasi secara terang terangan dan tersamardan observasi yang tidak tersetruktur. Adapun fakta atau fenomena yang akan diobservasi langsung oleh peneliti adalah peran serta masyarakat dalam implementasi Manajemen Berbasis Sekolah pada Pendidikan Dasar di kecamatan Pantai Labu.

Wawancara. Dalam penelitian ini, wawancara dilakukan dengan kepala sekolah, guru, masyarakat dan pihak-pihak pendukungyang relevan dengan konteks penelitian yang sekiranya dapat memberikan datainformasi. Dalam melakukan wawancara, peneliti menggunakan teknik wawancarasemi terstruktur (semi-structured interview).

Dokumentasi. Dokumentasi merupakan benda-benda tertulis seperti buku-buku, majalah, dokumen, peraturan-peraturan, dan lain-lain. Dalam penelitian kualitatif, teknik dokumentasi ini digunakan untuk menghimpun berbagai data yang memuat informasi tertentu yang bersumber dari dokumen-dokumen tertulis. Adapun dalam hal ini dokumentasi yang dimaksud berupa foto-foto, dokumen komite sekolah, arsiparsip, dan dokumen pendukung yang lain.

Setelah data yang diperlukan terkumpul, maka seluruh data akan dianalisis dengan metode berpikir ilmiah, yakni dengan cara mendeskripsikan, menghubungkan dan membandingkan beberapa komponen temuan di lapangan. Adapun tahap-tahap analisis data yang digunakan dalam penelitian ini sesuai yaitu reduksi data, penyajian data, dan penarikan simpulan.

Reduksi data yaitu proses pemilihan, pemusatan perhatian padapenyederhanaan, abstraksian, dan transformasi data mentah yang ada dalamsemua bentuk catatan di lapangan. Dengan demikian data yang sudah direduksiakan memberikan gambaran yang jelas, dan mempermudah peneliti untukmelakukan pengumpulan data selanjutnya serta mencarinya jika diperlukan.Pada penelitian ini data yang telah diperoleh kemudian dipilih,diseleksi dan dirangkum, serta difokuskan pada halhal yang berkaitan peran serta masyarakat dalam implementasi Manajemen Berbasis Sekolah pada Pendidikan Dasar Kecamatan Pantai Labu.

Penyajian data yaitu suatu kegiatan penyusunan sekumpulan informasi dalam bentuk yang terorganisir yang memberikan kemungkinan adanya penarikan kesimpulan dalam bentuk narasi atas kategori atau pola 
tertentu dan penarikan tindakan. Dalam penelitian ini, secara teknis data-data akan disajikan dalam bentuk teks naratif, tabel,foto dan bagan.Kegiatan analisis terakhir adalah penarikan kesimpulan dan verifikasi.

Penarikan Kesimpulan/verifikasi yakni membuat kesimpulan dalam bentuk narasi atas kategori dan pola tertentu menurut pandangan informan secara terus menerus selama penelitian berlangsung. Selain itu secara teknis peneliti juga melakukan interprestasi menafsirkan kategori atau pola tertentu berdasarkan sudut pandang informan yang telah disusun sebelumnya baik melalui pengomparasian, mendialogkan, serta memperbandingkanya dengan konsep, model, pikiran atau teoriteori yang dimasukan dalam bab tinjauan pustaka

\section{HASIL DAN PEMBAHASAN}

Hasil yang dicapai dalam penelitian yang telah dilakukan selama enam bulan diperoleh temuan diantaranya: kondisi kecamatan Pantai Labu merupaka salah satu kecamatan yang dekat dengan ibu kota kabupaten yaitu Lubuk Pakam, Kecamatan Pantai Labu merupakan salah satu kecamatan yang hamper seluruhnya berada di pesisir pantai timur pulau Sumatera.

\section{Profil Kecamatan Pantai Labu}

Kabupaten Deli Serdang terdiri dari 22 kecamatan. Lubuk Pakam merupakan ibu kota dari Kabupaten Deli Serdang. Pantai
Labu adalah sebuah kecamatan di Kabupaten Deli Serdang, Sumatra Utara, Indonesia.dengan jumlah penduduk 50.953 (2017). Kecamatan Pantai labu terdiri dari 19 Desa/Kelurahan. Terdapat 21 Sekolah Dasar Negeri dan 3 Sekolah Dasar Swasta yang ada di kecamatan Pantai Labu Kabupaten Deli Serdang.

\section{Peran Serta Masyarakat}

Di dalam UU No. 20/2003 tentang Sisdiknas. Pada Bab XV Pasal 54 dinyatakan bahwa peran serta masyarakat dalam pendidikan meliputi peran serta perseorangan, kelompok, keluarga, organisasi profesi, pengusaha, dan organisasi kemasyarakatan dalam penyelenggaraan dan pengendalian mutu layanan pendidikan. Pendidikan atau sekolah mempunyai hubungan yang erat dengan masyarakat karena saling membutuhkan satu sama lain. Pengembangan konsep MBS didesain untuk meningkatkan kemampuan sekolah dan masyarakat dalam mengelola perubahan pendidikan, kaitannya dengan tujuan keseluruhan, kebijakan, strategi perencanaan, inisiatif kurikulum yang telah ditentukan oleh pemerintah dan otoritas pendidikan (Sulaeman, 2018). Pendekatan MBS menuntut adanya perubahan tingkah laku seluruh komponen sekolah, kepala sekolah, guru dan tenaga/staff administrasi, termasuk orang tua dan masyarakat dalam memandang, memahami, membantu sekaligus pemantau yang melaksanakan monitoring dan evaluasi dalam pengelolaan 
system informasi yang representatif dan valid. Pihak sekolah bersama-sama dengan orang tua dan masyarakat harus membuat keputusan, mengatur skala prioritas, di samping harus menyediakan lingkungan kerja yang lebih professional bagi guru dan meningkatkan pengetahuan dan kemampuan serta keyakinan masyarakat tentang sekolah/pendidikan. Sekolah harus bisa mengajak kerjasama pihak masyarakat untuk meningkatkan mutu pendidikan. Hal ini dapat dilakukan dengan cara pemberian kepada orang tua siswa untuk dapat berkunjung kesekolah membicarakan masalah khusus yang muncul pada anaknya (open door politics), kunjungan sekolah kerumah siswa (home visiting), penggunaan resources persons, kunjungan sekolah keobjek-objek tertentu dimasyarakat, pertemuan antara orang tua dan warga sekolah, mengefektifkan BP3, dan masih banyak lagi cara yang bisa dilakukan (Wahyudi, 2012)

Masyarakat dan peningkatan mutu sekolah merupakan dua hal yang tak dapat dipisahkan karena, salah satu prinsip yang ada dalam MBS yaitu adanya partisipasi/ peran serta masyarakat untuk meningkatkan mutu sekolah/ pendidikan. Namun, selama ini peran serta masyarakat khususnya orang tua siswa dalam penyelenggaraan pendidikan masih sangat minim. Partisipasi masyarakat selama ini pada umumnya sebatas pada dukungan dana, sementara dukungan lain seperti pemikiran, moral, dan barang/jasa kurang diperhatikan oleh karena itu untuk memperbaikinya perlu dilakukan suatu upaya-upaya perbaikan, salah satunya adalah melakukan reorientasi penyelenggaraan pendidikan dengan melibatkan peran serta masyarakat melalui manajemen peningkatan mutu berbasis sekolah.

Kunjungan tim peneliti ke kantor Koordinator Wilayah Kecamatan Bidang pendidikan Kecamatan pantai labu dilakukan sebelum dan setelah melakukan penelitian ke sekolah dan desa yang berada di kecamatan pantai labu. kunjungan dilakukan dalam hal pengurusan izin penelitian dan wawancara mengenai hasil kunjungan lapangan yaitu ke 16 Sekolah Dasar Negeri dan 4 Kantor Desa.

Berdasarkan hasil observasi, wawancara dan dokumentasi di 16 Sekolah Dasar Negeri dan 4 Kantor Desa kecamatan Pantai labu, peneliti menilai bahwa Peran Serta Masyarakat sudah tertuang dalam bentuk Komite Sekolah, Susunan komite sekolah terdiri dari orang tua siswa dan tokoh masyarakat setempat. Partisipasi komite sekolah lebih banyak terlibat dalam penyusunan program sekolah, sedangkan dalam pengawasan pelaksanaan program sekolah masih minim.

Di dalam UU No. 20/2003 tentang Sisdiknas. Pada Bab XV Pasal 54 dinyatakan bahwa:

peran serta masyarakat dalam pendidikan meliputi peran serta perseorangan, 
kelompok, keluarga, organisasi profesi, pengusaha, dan organisasi kemasyarakatan dalam penyelenggaraan dan pengendalian mutu layanan pendidikan. Masyarakat dapat berperan serta sebagai sumber pelaksana dan pengguna hasil pendidikan. Ketentuan mengenai peran serta masyarakat sebagaimana dimaksud pada ayat (1) dan (2) diatur lebih lanjut dengan peraturan pemerintah

Bentuk-bentuk peran serta masyarakat dalam peningkatan mutu sekolah diantaranya 1) menggunakan jasa sekolah, 2) memberikan kontribusi dana, bahan, dan tenaga, 3) membantu anak belajar di rumah, 4) berkonsultasi masalah pendidikan anak, 5) terlibat dalam kegiatan ekstra kurikuler, dan 6) pembahasan kebijakan sekolah.

Dukungan masyarakat terhadap peningkatan mutu pendidikan sekolah melibatkan peran serta tokoh-tokoh masyarakat dan tokoh agama, dunia usaha dan dunia industri, serta kelembagaan sosial budaya. Penyertaan mereka dalam pengelolaan sekolah hendaknya dilakukan secara integral, sinergis, dan efektif, dengan memperhatikan keterbukaan sekolah untuk menumbuhkan rasa memiliki dan tanggung jawab masyarakat dalam meningkatkan mutu sekolah. Berdasarkan hasil observasi, wawancara dan dokumentasi yang diperoleh oleh peneliti, peran serta masyarakat yang ada di sekolah-sekolah yang ada di lokasi penelitian belum sepenuhnya sesuai dengan amanat Undang-Undang Sistem pendidikan nasional diatas.

\section{Komite Sekolah}

Seperti dijelaskan dalam Kepmendiknas Nomor 044/U/2002 tentang Dewan Pendidikan dan Komite Sekolah, peran Komite Sekolah tidak sekedar membantu sekolah dalam penggalangan dana. Komite sekolah mempunyai peran yang jauh lebih luas, yaitu 1) pemberi pertimbangan (advisory agency) dalam penentuan dan pelaksanaan kebijakan pendidikan, 2) pendukung (supporting agency), baik yang berwujud financial, pemikiran maupun tenaga dalam penyelenggaraan pendidikan, 3) pengontrol (controlling agency) dalam rangka transparansi dan akuntabilitas penyelenggaraan dan keluaran pendidikan, 4) mediator antara pemerintah (eksekutif) dan Dewan Perwakilan Rakyat Daerah (legislatif) dengan masyarakat.

Untuk menjalankan peran yang demikian besar, Komite Sekolah berjalan secara mandiri, dalam arti tidak di bawah koordinasi kepala sekolah, melainkan berkerjasama dengan kepala sekolah untuk memajukan sistem pendidikan di sekolahnya. Peraturan Pemerintah Nomor 17 Tahun 2010 tentang Pengelolaan dan Penyelenggaraan Pendidikan Pasal 196 secara jelas mengatur fungsi dan tugas Komite Sekolah/Madrasah. Pada pasal 196 ayat (1): Komite Sekolah/Madrasah berfungsi dalam peningkatan mutu pelayanan pendidikan dengan memberikan 
pertimbangan, arahan dan dukungan tenaga, sarana dan prasarana, serta pengawasan pendidikan pada tingkat satuan pendidikan. Pasal 196 ayat (2): Komite Sekolah/Madrasah menjalankan fungsinya secara mandiri dan profesional. Pasal 196 ayat (3): Komite Sekolah/Madrasah memperhatikan dan menindaklanjuti terhadap keluhan, saran, kritik, dan aspirasi masyarakat terhadap satuan pendidikan.

Berdasarkan butir-butir ayat tersebut jelas bahwa Komite Sekolah memiliki peran penting dalam upaya memajukan dunia pendidikan di tingkat nasional, provinsi, dan kabupaten/kota. Komite Sekolah juga turut memberikan pertimbangan mengenai berbagai isu pendidikan. Posisi ini menjadikan Komite Sekolah sebagai mitra strategis dan sejajar bagi sekolah dalam penyelenggaraan pendidikan. Komite Sekolah sebagai wakil masyarakat sedianya menyuarakan kepentingan dan kebutuhan masyarakat dalam berbagai kebijakan pendidikan yang diambil sekolah.

\section{Hambatan Peran Komite Sekolah}

Masalah yang terjadi di lokasi penelitian, kehadiran komite sekolah hanyalah sebagai bagian formalitas semata, dan pihak orangtua atau wali murid juga tidak mengetahui secara mendalam fungsi dah peran komite sekolah di tiap satuan pendidikan. Tidak sedikit yang beranggapan bahwa komite sekolah memiliki peran seperti BP3 di masa lampau, yaitu badan yang bertugas sebagai pengumpul dana bantuan untuk pendidikan atau badan justifikasi belaka. Pemberlakuan manajemen berbasis sekolah membawa implikasi kepada sekolah tidak menjadi subordinat lagi dari pemerintah maupun yayasan, tetapi bersifat otonom. Pendekatannya pun tidak birokratis lagi, melainkan profesional. Ruang gerak para guru dan kepala sekolah menjadi lebih luas dan leluasa, termasuk dalam mengelola anggaran pendidikan di sekolah. Akan tetapi, di beberapa daerah banyak temuan tentang problematika komite sekolah ini.

Beberapa permasalahan yang ditemukan dalam penelitian berkenaan dengan komite sekolah diantarannya 1) komite sekolah seharusnya ikut bertanggungjawab dalam penyususan perencanaan strategis dan rencana tahunan sekolah, perumusan kebijakan sekolah, pemenuhan kebutuhan sekolah, menilai keberhasilan pelaksanaan program-program yang dilaksanakan sekolah serta ikut mensyahkan laporan sekolah tahunan. Namun kenyataan yang terjadi, komite sekolah belum berperan aktif sebagaimana uraian diatas. 2) Fungsi organisasi juga masih perlu pembenahan. Banyak kasus anggota komite sekolah dibentuk tidak melalui prosedur yang benar. Para anggotannya tidak tahu tugas pokok dan fungsinya. 3) Kurang adanya informasi pengarahan secara berkelanjutan tentang membuat komite sekolah yang ideal, tugas dan fungsi komite sekolah. 


\section{SIMPULAN DAN SARAN}

Berdasarkan deskripsi data, temuan penelitian dan pembahasan hasil penelitian, maka secara umum dapat disimpulkan bahwa Peran Serta Masyarakat dalam Implementasi Manajemen Berbasis Sekolah (MBS) pada Pendidikan Dasar di Kecamatan Pantai Labu adalah 1) peran Aktif Masyarakat sebagai bagian dari implementasi manajemen berbasis sekolah di Kecamatan Pantai Labu Kapupaten Deli Serdang Provinsi Sumatera Utara masih belum berjalan maksimal, hal tersebut terjadi karena kurangnya pelatihan dalam penyusunan tugas dan fungsi komite sekolah. Komite Sekolahmasih terfokus pada pemenuhan struktur sekolah saja. komite sekolah belum difungsikan secara maksimal sebagaimana mestinya, 2) faktor yang mendukung implementasi peran aktif masyarakat sebagai bagian dari implementasi manajemen berbasis sekolah di Kecamatan Pantai Labu Kapupaten Deli Serdang Provinsi Sumatera Utaraadalah sudah terbentuknya komite sekolah di setiap sekolah yang ada. 3) faktor yang menghambat implementasi Peran Aktif Masyarakat sebagai bagian dari implementasi manajemen berbasis sekolah di Kecamatan Pantai Labu Kapupaten Deli Serdang Provinsi Sumatera Utara adalah masih lemahnya pemahaman tentang peran dan fungsi komite sekolah dalam memajukan pendidikan.
Pada intinya, untuk mengoptimalkan peran serta masyarakat, maka diperlukan pendampingan perangkat sekolah dalam menyusun tugas dan fungsi komite sekolah.

\section{DAFTAR REFERENSI}

Aziz, A. Z. (2015). Manajemen Berbasis Sekolah (Alternatif Peningkatan Mutu Pendidikan Madrasah). EL-TARBAWI: Jurnal Pendidikan Islam, $\quad 8(1), \quad$ 70-92. https://doi.org/10.30863/ekspose.v17i2.117

Prayudi. (2014). Desentralisasi dalam Sistem Pemerintahan Indonesia: Politik Negara di Tengah Hubungan Pusat-Daerah. Kajian, 19(4), 293-310.

Risno, D. N. (2015). Implementasi Manajemen Berbasis Sekolah Pada Aspek Peran Serta Masyarakat di Sekolah Menengah Atas Negeri 1 Padang. Administrasi Pendidikan, 3(2), 777-785.

Sulaeman, M. (2018). Urgensi Manajemen Peningkatan Mutu Berbasis Sekolah di Lembaga Pendidikan Islam. Realita, 16(1), 1-19.

Umaedi, Hadiyanto, \& Siswantari. (2015). Manajemen Berbasis Sekolah. https://doi.org/10.24256/jpmipa.v1i1.86 Wahyudi, I. (2012). Pengembangan Pendidikan, Strategi Inovatif dan Kreatif dalam Mengelola Pendidikan secara Konfrehensif. Jakarta: Prestasi Pustaka Raya.

Wicaksono, A. G. (2018). Fenomena Full Day School dalam Sistem Pendidikan Indonesia. Jurnal Komunikasi Pendidikan, l(1), 10. https://doi.org/10.32585/jkp.v1i1.12 